Ann. rheum. Dis. (1964), 23, 131.

\title{
RHEUMATOID ARTHRITIS WITH AMYLOIDOSIS
}

\author{
BY \\ K. ENNEVAARA AND MARTTI OKA* \\ Rheumatism Foundation Hospital, Heinola, Finland (Director: Dr. V. Laine)
}

Secondary amyloidosis in patients with rheumatoid arthritis is a dangerous complication which accounts for a significant number of early deaths (Gedda, 1955). Although it is not rare, most of the reported cases were not diagnosed until after death. Missen and Taylor (1956) reviewed the relevant literature and found 97 cases in which the diagnosis of amyloidosis was made at autopsy, and only 28 in which it was made during life. The largest post-mortem series of cases of rheumatoid arthritis with amyloidosis (Teilum and Lindahl, 1954) comprises seventeen patients, in only one of whom had amyloidosis been diagnosed clinically. The largest ante-mortem series are those of Unger, Zuckerbrod, Beck, and Steele (1948) with six cases and of Fearnley and Lackner (1955) with eight cases.

\section{Diagnosis}

Congo Red Test.-The diagnosis of amyloidosis in living patients was formerly based mainly on the Congo red test, but the Congo red affinity of sera from patients with rheumatoid arthritis is decreased, evidently owing to the lowered serum albumin and also to the competition of Congo red with polysaccharide anions, which are increased in rheumatoid arthritis (Larsen, 1958). The Congo red test has also been shown to give false negative results in a significant proportion of histologically-proven cases of amyloidosis (Blum and Sohar, 1962).

Renal Biopsy.-This is a more reliable method of diagnosis (Heptinstall and Joekes, 1960), but renal needle biopsy is not without risk. In an analysis of 5,000 cases, Slotkin and Madsen (1962) found 0.7 per cent. of severe complications, especially perirenal haematoma.

Rectal Biopsy.-The use of rectal biopsy in the diagnosis of amyloidosis, which was introduced by Gafni and Sohar (1960), involves no risk and is

\footnotetext{
* Present Address: University Hospital, Turku, Finland.
}

simple to perform. This method yielded 75 per cent. of positive results, as against 87 per cent. of positive results with renal biopsy in a series of cases of amyloidosis of varying aetiology (Blum and Sohar, 1962).

Proteinuria.-This is bound to occur sooner or later in cases of renal amyloidosis associated with rheumatoid arthritis (Fingerman and Andrus, 1943; Unger, Zuckerbrod, Beck, and Steele, 1948; Missen and Taylor, 1956; Rubens-Duval and Villiaumey, 1959). Its significance as a clinical sign of amyloidosis was stressed by Teilum and Lindahl (1954) and Fearnley and Lackner (1955). Amyloidosis caused proteinuria in at least eight out of 24 cases studied by the last-mentioned workers, and in four out of thirteen cases of rheumatoid arthritis studied by renal biopsy by Pollak, Pirani, Steck, and Kark (1962).

\section{Diagnosis}

\section{PRESENT SERIES}

The presence of proteinuria in 24 cases of arthritis led to their investigation for possible amyloidosis, by renal, rectal, and lymph node biopsy. Amyloidosis was found to be present in seventeen ( 3 males and 14 females) and absent in seven ( 3 males and 4 females) (Tables I and IA, overleaf).

Renal biopsies of 21 patients revealed amyloidosis in fifteen (Cases 1 to 15).

Rectal biopsies of nine cases (Cases 8 to 16) confirmed the presence of amyloidosis in six of the positive renal cases (Cases 8 to 13), and revealed it in one of the negative renal cases (Case 16); this test also gave a doubtful result in two positive renal cases (Cases 14 and 15).

Lymph node biopsy of one other patient (Case 17) also gave a positive result.

The proteinuria was moderate to strong in thirteen of the seventeen positive cases and in six of the seven negative cases. 
TABLE

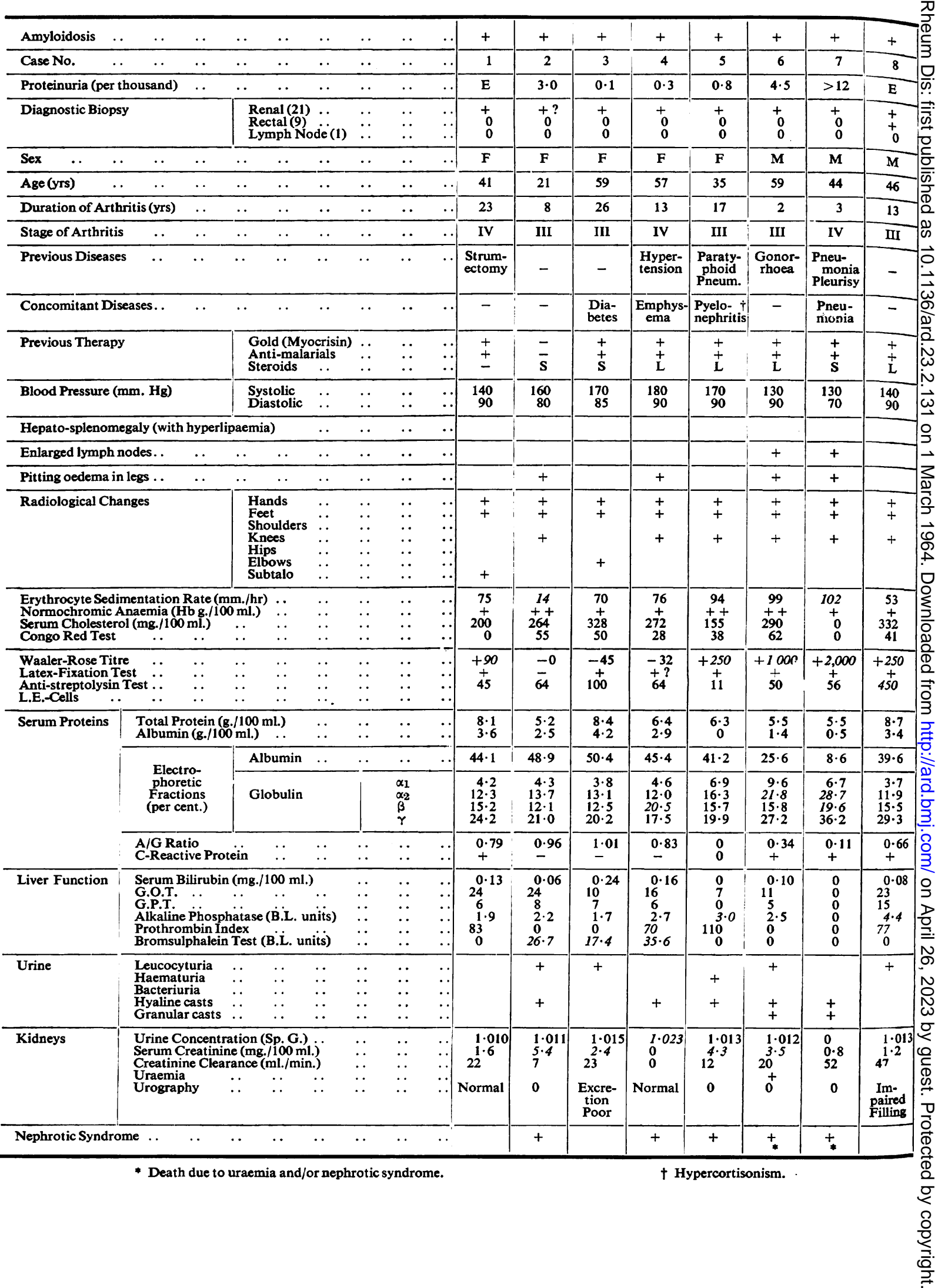


TABle IA

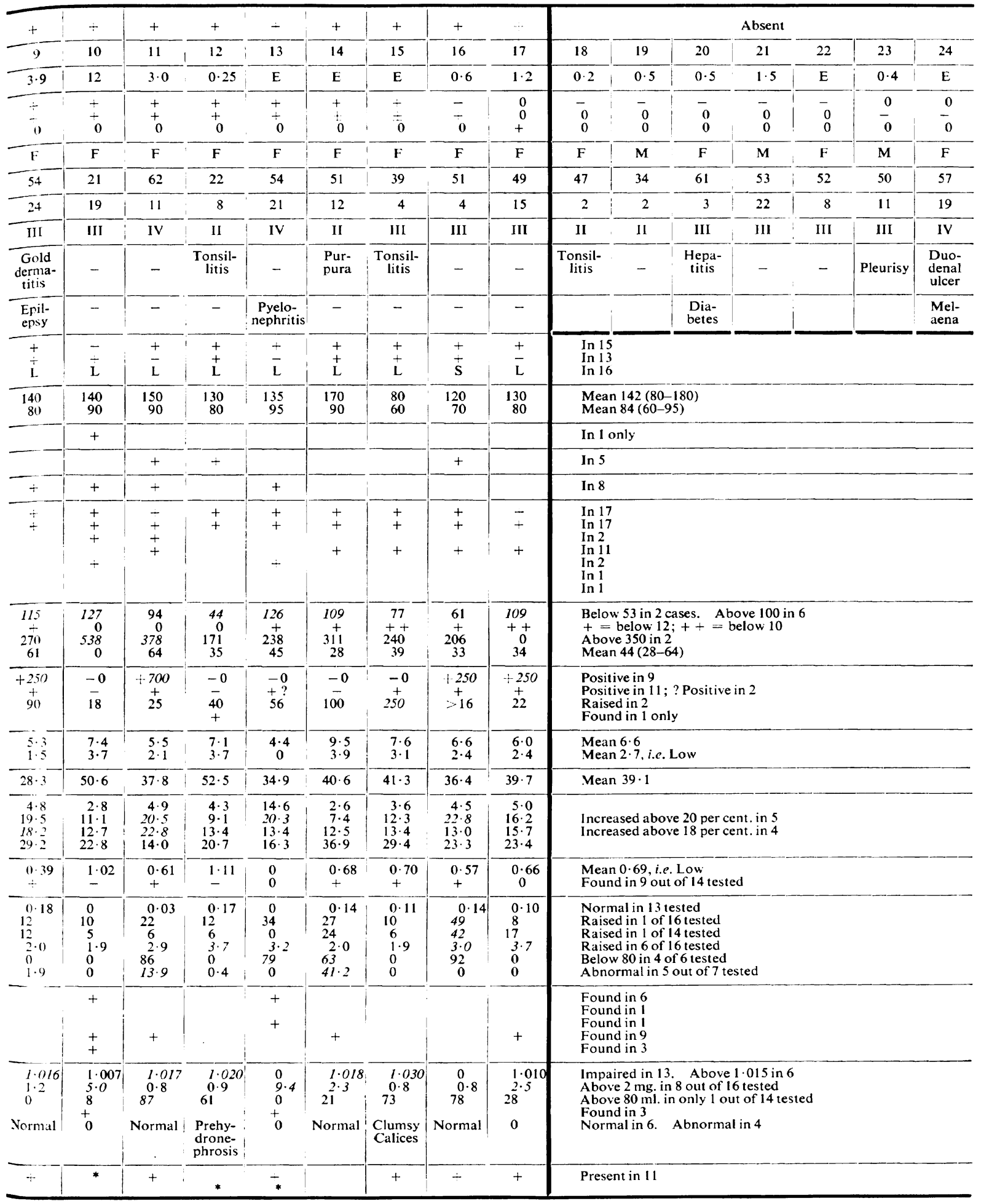


Controls.-Ten severe cases of rheumatoid arthritis of Stage III or IV, and with a duration of disease of 5 to 33 years (average 14), but without proteinuria, were also subjected to rectal biopsy, but none showed any evidence of amyloidosis.

\section{Clinical Picture}

The best study so far reported of rheumatoid arthritis with amyloidosis is that of Unger and others (1948), who based the diagnosis of their six cases on the Congo red test in four and a liver biopsy in two, and whose main observations included:
Albuminuria (6)
Hepatomegaly (5)
Hypoalbuminaemia (2)
Oedema (5)
Splenomegaly (4)
Decreased urea clearance (5)
Anaemia (5)
Normal blood pressure (6)

Because the available information is so scanty we have made a very detailed study of our seventeen cases.

Patients.-There were three males among the seventeen cases with amyloidosis. The mean age of the whole series was 45 years (range 21 to 62). The average duration of rheumatoid arthritis was 13 years (range 2 to 26) when the diagnosis of amyloidosis was established.* The disease had begun in childhood in Case 2 (at age 13) and in Case 10 (at age 3).

Stage of Arthritis (Steinbrocker, Traeger, and Batterman (1949).- Two cases were in Stage II, ten in Stage III, and five in Stage IV.

Previous Diseases.-These included acute tonsillitis (2), pneumonia (2), paratyphoid (1), gonorrhoea (1), exudative pleuritis (1), strumectomy (1), purpura (1), gold dermatitis (1), hypertension (1).

Concomitant Diseases. - These included urinary infection (2), diabetes (1), interstitial pneumonia (1), pulmonary emphysema (1), epilepsy (1), and hypercortisonism (1).

\section{Previous Therapy}

Gold Salts.-Fifteen patients had received injections of myocrisin. Eleven had had an average of fifteen injections (range 6 to 40), and the four others had been treated for an average of 1.4 years (range 0.5 to 3 ).

Antimalarial Drugs.-These had been administered in thirteen cases.

Steroids or ACTH.-These had been given to all but one case. Four patients had received short-term

\footnotetext{
* According to Missen and Taylor (1956), the mean duration of arthritis when amyloidosis was established during life was 5.9 years for 28 cases, but was 12.8 years in the 97 cases diagnosed post mortem. Amyloidosis was only rarely found before the arthritis had been present for 2 years.
}

treatment ( 1 week to 3 months), and twelve long-term treatment (4 months to 12 years; average $3 \cdot 8)$. Eight patients had received hormones for more than 2 years and five for more than 4 years. The exact total dose of steroids or ACTH could not be calculated. Prolonged steroid administration was still being carried on in five cases when the amyloidosis was discovered.

\section{General Examination}

Blood Pressure.-This was not markedly raised (systolic 80 to $180 \mathrm{~mm}$. Hg (average 142) and diastolic 60 to $95 \mathrm{~mm}$. $\mathrm{Hg}$ (average 84).

Hepato-splenomegaly.-This was present only in one patient (Case 10), who also proved to have hyperlipaemia.

Enlarged Lymph Nodes.-These were found by palpation in five patients (Cases 6, 7, 11, 12,16).

Pitting Oedema in the Legs.-This was observed in eight patients, in three of whom it was very slight.

Radiological Changes.-These were seen in the hands (17), feet (17), knees (11), shoulders (2), hips (2), elbows (1), and subtalo joints (1). In most cases the joint symptoms were symmetrical and in all they were characteristic of rheumatoid arthritis.

\section{Laboratory Data}

Erythrocyte Sedimentation Rate.-Average 85 $\mathrm{mm}$./1st hr (range 14 to 127). Only in Case 2 (14) and Case 12 (44) was it below 53. In six cases it exceeded 100.

Normochromic Anaemia (Hb $<12$ g./100 ml.) was present in fourteen cases, five of which (Cases 2, $5,6,15,17)$ had $\mathrm{Hb}$ values below $10 \mathrm{~g}$. The average Hb was $10 \cdot 76$ (range $9 \cdot 1$ to $12 \cdot 4$ ).

Serum Cholesterol.-Average $279 \mathrm{mg} . / 100 \mathrm{ml}$. (range 155 to 538) in fifteen cases measured. Only two cases showed values above 350 (Case 11 (378) and Case 10 (538).

Congo Red.-Average disappearance from blood after 1 hour 44 per cent. (range 27.6 to 67 ) in fourteen cases tested.

\section{Serology}

WAALER-ROSE TEST: positive in nine cases with titres from 90 to 2,000. Titres above 250 occurred in only three cases $(6,7$, and 11$)$.

LATEX-FIXATION TEST: positive in eleven cases, and possibly positive in two others.

Data on earlier determinations of the rheumatoid factor were available in eleven cases in which the observation period varied from 2 months to 3 years; 
the Waaler-Rose titre had fallen in one (Case 15) from 250 to 0 , and in another case the latex-fixation test had changed from positive to negative (Case 12). The Waaler-Rose titre fell in four cases $(8,12,15,16)$ and rose in two (6 and 9) (Table II). $(8,15)$.

ANTISTREPTOLYSIN TITRE: raised in two cases

L.E.-CELLS: demonstrated in the peripheral blood in Case 12 only.

Serum Proteins.-The mean results (Table III) demonstrates a tendency towards a nephrotic syndrome, i.e. hypoalbuminaemia, low $\mathrm{A} / \mathrm{G}$ ratio, and increased $\alpha_{2}$ and $\beta$-globulin fractions. The individual variations were large (Table I). Serum albumin was below $3.5 \mathrm{~g} . / 100 \mathrm{ml}$. in ten cases. The $\alpha_{2}$-globulin fraction was above 15 per cent. in eight, and above 20 per cent. in five. The $\beta$-globulin fraction exceeded 18 per cent. in four cases.

C-REACTIVE PROTEIN: appeared in the peripheral blood in nine cases.

\section{Liver Function}

SERUM BILIRUBIN: normal in all of thirteen cases tested.

GOT AND GPT: raised in Case 16 only.

ALKALINE PHOSPHATASE: slightly raised $(3 \cdot 0$ or above) in six cases.

PROTHROMBIN INDEX: decreased to less than 80 per cent. (21 to 37 ) in four cases.

BROMSULPHALEIN TEST: abnormal in five of seven cases.

\section{Urine}

Proteinuria was constant in thirteen cases and transient in four. Esbach values ranged from 0.1 to over 12 per thousand, being above 0.5 per thousand in ten cases. The proteinuria was discovered on an average $2 \frac{1}{2}$ years earlier than the amyloidosis, and 1 to 23 years after the onset of arthritis.

TABLE II

SEROLOGICAL CHANGES IN ELEVEN CASES IN THE COURSE OF 2 TO 24 MONTHS

\begin{tabular}{|c|c|c|c|c|c|c|}
\hline \multirow{2}{*}{ Case No. } & \multicolumn{3}{|c|}{ First Examination } & \multirow{2}{*}{ Interval (mths) } & \multicolumn{2}{|c|}{ Second Examination } \\
\hline & $\begin{array}{c}\text { Waaler-Rose } \\
\text { Titre }\end{array}$ & Latex Test & $\begin{array}{c}\text { Bentonite } \\
\text { Test }\end{array}$ & & $\begin{array}{c}\text { Waaler-Rose } \\
\text { Titre }\end{array}$ & Latex Test \\
\hline 3 & 0 & 0 & + & 24 & 45 & + \\
\hline 4 & 0 & 0 & + & 24 & 32 & + \\
\hline 6 & 500 & + & 0 & 2 & 1,000 & + \\
\hline 7 & 0 & + & + & 36 & 2,000 & + \\
\hline 8 & 2,000 & + & 0 & 12 & 250 & + \\
\hline 9 & 180 & + & 0 & 6 & 250 & + \\
\hline 10 & 0 & - & 0 & 12 & 0 & - \\
\hline 12 & 32 & + & 0 & 12 & 0 & - \\
\hline 14 & 0 & 0 & - & 36 & 0 & - \\
\hline 15 & 250 & + & 0 & 24 & 0 & + \\
\hline 16 & 1,000 & + & 0 & 4 & 250 & + \\
\hline
\end{tabular}

$0=$ Not done.

TABLE III

SERUM PROTEIN ESTIMATIONS

\begin{tabular}{|c|c|c|c|c|c|c|c|c|c|}
\hline \multirow{2}{*}{ Estimations } & \multicolumn{4}{|c|}{ Serum Proteins (g. $/ 100 \mathrm{ml})}$. & \multicolumn{5}{|c|}{ Electrophoretic Fractions (per cent.) } \\
\hline & Albumin & Globulin & Total & $\mathrm{A} / \mathrm{G}$ ratio & Albumin & Alpha 1 & Alpha 2 & Beta & Gamma \\
\hline $\begin{array}{ll}\text { Mean } & \ldots \\
\text { Range } & \ldots\end{array}$ & $\begin{array}{c}2 \cdot 7 \\
0 \cdot 5-4 \cdot 2\end{array}$ & $2 \cdot 3 \cdot 9$ & $\begin{array}{c}6 \cdot 6 \\
4 \cdot 4-9 \cdot 5\end{array}$ & $\begin{array}{c}0.69 \\
0 \cdot 11-1 \cdot 11\end{array}$ & $\begin{array}{c}39 \cdot 3 \\
8 \cdot 6-52 \cdot 5\end{array}$ & $\begin{array}{c}5 \cdot 3 \\
2 \cdot 6-14 \cdot 6\end{array}$ & $\begin{array}{c}15 \cdot 8 \\
7 \cdot 4-28 \cdot 7\end{array}$ & $\begin{array}{c}15 \cdot 4 \\
12 \cdot 1-22 \cdot 8\end{array}$ & $\begin{array}{c}24 \cdot 2 \\
14 \cdot 0-36 \cdot 9\end{array}$ \\
\hline
\end{tabular}


Leucocyturia occurred in six, haematuria in one, and bacteriuria in one.

Hyaline casts were found in nine and granular casts in three.

Renal Function.-This was impaired in thirteen cases. The specific gravity in the urine concentration tests varied from $1 \cdot 010$ to $1 \cdot 030$, being above $1 \cdot 015$ in only six.

SERUM CREATININE: range 0.8 to $9.4 \mathrm{mg} . / 100$ $\mathrm{ml}$., above $2 \mathrm{mg}$. in eight cases.

CREATININE CLEARANCE: decreased (below 80 $\mathrm{ml} . / \mathrm{min}$.) in thirteen cases of fourteen tested (average $39 \mathrm{ml} . / \mathrm{min}$.; range 7 to 87 ). This test was not performed in Cases 4 and 9, in which the concentration test or serum creatinine were normal, or in Case 13 in which the serum creatinine was $9 \cdot 4 \mathrm{mg}$. $/ 100 \mathrm{ml}$. uraemia.

Three patients $(6,10,13)$ suffered from

Urography was normal in six cases, and four abnormal urograms showed impaired excretion (3), impaired filling (8), clumsy calices (15), and prehydronephrosis (12).

Nephrotic Syndrome.-This was clinically evident in eleven cases; the other six cases $(1,3,8,10$, $12,14)$ all having impaired renal function manifested as decreased creatinine clearance. The one patient (Case 10) whose liver and spleen were enlarged had a florid amyloid nephrosis with hyperlipaemia.

In five patients death was due to uraemia and/or nephrotic syndrome (Cases 6, 7, 10, 11, 13).

\section{Discussion}

Rectal biopsy thus appears to be a very reliable method of diagnosing amyloidosis in cases of rheumatoid arthritis. It is easy to perform, devoid of risk, and gives results comparable with those of renal biopsy, and far superior to those of the Congo red test.

Proteinuria was the indication for a search for amyloidosis in our cases, and the high incidence of positive cases ( 17 out of $24: 70 \cdot 8$ per cent.), suggests that amyloidosis is the most important cause of proteinuria in rheumatoid arthritis. Our series was taken at random, but all the patients admitted to the Rheumatism Foundation Hospital are selected in as much as they rarely include those with severe concomitant illnesses.

None of our ten "control cases", who were rheumatoid arthritics with severe, long-term disease but without proteinuria, gave positive rectal biopsies. Laine, Vainio, and Ritama (1955) found "amyloidlike material" in about 50 per cent. of biopsies of various tissues in cases of rheumatoid arthritis, especially in the joints and surrounding superficial structures and the skin, but proteinuria was present in only two out of a hundred (Laine, Mäkinen, Mäkinen, Holopainen, and Sairanen, 1955). It appears that the cases in their series do not represent true amyloid disease, the clinical diagnosis of which must be based on visceral biopsy findings.

The clinical picture of rheumatoid arthritis was characteristic of far-advanced disease, but the number with a positive Waaler-Rose or latex-fixation test was lower than would be expected in such cases (Wager, Ripatti, Laine, Julkunen, and Aho, 1961). This may support the theory of Latvalahti (1953) that the amyloid formation is provoked by some stimulus that places an added strain on the antibodyforming system. Under this strain the immunization mechanism gradually becomes exhausted, and the antibody level in the blood inadequate; the excess of antigen in the blood then causes an antigen-antibody reaction (i.e. a precipitation of amyloid) at the site of antibody formation.

The effect of cortisone in promoting amyloid formation has also been experimentally demonstrated by Teilum (1952) and Latvalahti (1953). The former believed that the amyloid phase might be a perverted phase of the cellular synthesis of protein, the amyloidosis resulting from an imbalance in the interaction of ascorbic acid and cortisone. The latter considered that cortisone, which suppresses antibody formation, may simultaneously accelerate the antigen-antibody reaction and cause the precipitation of amyloid at the site of antibody formation. The clinical correlation between amyloidosis and steroid treatment is not clear. Parkins and Bywaters (1959) found that steroid hormones did not increase the clinical signs of amyloidosis, and might even have induced remissions in two cases. Gardner (1962) studied the necropsy records of 108 cases of rheumatoid arthritis, 54 from the precortisone era, and found no increase in secondary amyloidosis through the use of hormones. By contrast, twelve of our patients had received longterm steroid treatment, and four short-term.

In the majority of our cases, the clinical picture of renal amyloidosis was that of a nephrotic syndrome, with moderate or marked proteinuria, lowered serum albumin, low A/G ratio, raised alpha 2 and betaglobulin, pitting oedema, normal blood pressure, and impaired renal function. Only Case 10 showed hepato-splenomegaly with marked hyperlipaemia. Some liver function tests were abnormal in eleven cases, the most frequent change being an increased retention in the bromsulphalein test, an increase of alkaline phosphatase, and a decrease in the pro- 
thrombin index. When the proteinuria was mild, the renal involvement appeared as a functional disturbance, especially in decreased creatinine clearance. In some cases urine analysis revealed pyuria or haematuria, but the most constant finding was the excretion of hyaline casts.

We agree with Rubens-Duval and Villiaumey (1959) that hepato-splenomegaly is exceptional in rheumatoid amyloidosis, but in other respects our findings accord with those of Unger and others (1948). It should be specially emphasized that a normal blood pressure is characteristic of the amyloidosis of rheumatoid arthritis.

\section{Summary}

In seventeen cases of rheumatoid arthritis, secondary amyloidosis was diagnosed (by a renal and/ or rectal biopsy in sixteen and a lymph node biopsy in one). The indication for the biopsy was proteinuria. Special attention was paid to the reliability of rectal as opposed to renal biopsy in diagnosis, the significance of proteinuria, and the clinical picture of the disease.

The following observations were made:

(1) A rectal biopsy gave positive results in seven cases out of nine, while the renal biopsy of the same nine cases gave positive results in eight of them.

(2) Amyloidosis was diagnosed in seventeen out of 24 arthritics with proteinuria ( $70 \cdot 8$ per cent.).

(3) The clinical picture of rheumatoid arthritis complicated by amyloidosis did not differ significantly from the characteristic pattern of far-advanced arthritis. The mean duration of the rheumatoid arthritis was 13 years (range 2 to 26); the joint changes were Stage III or IV in fifteen cases; the mean E.S.R. was $85 \mathrm{~mm}$./hr; normochromic anaemia was present in fourteen; $C$-reactive protein could be demonstrated in the blood of nine; the Waaler-Rose test was positive in nine and the latex-fixation test in eleven.

Long-term steroid treatment had been given in twelve cases and short-term in four.

The renal amyloidosis appeared as a nephrotic syndrome in eleven cases, only one of which had spleno-hepatomegaly with marked hyperlipaemia. The remaining six cases with mild proteinuria all showed decreased creatinine clearance as a sign of renal damage.

The blood pressure was not clearly raised in any of these patients.

\section{REFERENCES}

Blum, A., and Sohar, E. (1962). Lancet, 1, 721.

Fearnley, G. R., and Lackner, R. (1955). Brit. med. J., $1,1129$.
Fingerman, D. L., and Andrus, F. C. (1943). Ann. rheum. Dis., 3, 168.

Gafni, J., and Sohar, E. (1960). Amer. J. med. Sci., 240, 332.

Gardner, D. L. (1962). Ann. rheum. Dis., 21, 298.

Gedda, P. O. (1955). Acta med. scand., 150, 443.

Heptinstall, R. H., and Joekes, A. M. (1960). Ann. rheum. Dis., 19, 126.

Laine, V., Mäkinen, P., Mäkinen, G.-L., Holopainen, T., and Sairanen, E. (1955). Acta rheum. scand., 1, 257.

—, Vainio, K., and Ritama, V. V. (1955). Ibid., $1,43$.

Larsen, B. (1958). Ann. rheum. Dis., 17, 240.

Latvalahti, J.(1953). Acta endocr. (Kbh.), Suppl. 16.

Missen, G. A. K., and Taylor, J. D. (1956). J. Path. Bact., 71, 179.

Parkins, R. A., and Bywaters, E. G. L. (1959). Brit. med.J., $1,536$.

Pollak, V. E., Pirani, C. L., Steck, I. E., and Kark, R. M. (1962). Arthr. and Rheum., 5, 1.

Rubens-Duval, A., and Villiaumey, J. (1959). Rev. Rhum., 26, 588.

Slotkin, E. A., and Madsen, P. O. (1962). J. Urol. (Baltimore), 87, 13.

Steinbrocker, O., Traeger, C. H., and Batterman, R. C. (1949). J. Amer. med. Ass., 140, 659.

Teilum, G. (1952). Ann. rheum. Dis., 11, 119.

and Lindahl, A. (1954). Acta med. scand., 149, 449.

Unger, P. N., Zuckerbrod, M., Beck, G. J., and Steele, J. M. (1948). Amer.J. med. Sci., 216, 51.

Wager, O., Ripatti, N., Laine, V., Julkunen, H., and Aho, K. (1961). Acta rheum. scand., 7, 209.

\section{Arthrite rhumatismale avec amyloidose}

\section{RÉSUMÉ}

En 17 cas d'arthrite rhumatismale on a fait le diagnostic d'amyloïdose secondaire par biopsie rénale et/ou rectale dans 16 cas et d'un ganglion lymphatique dans un cas. La biopsie était indiquée par la présence d'albuminurie. On a prêté attention spéciale à la valeur diagnostique de la biopsie rectale, par opposition à la rénale, à la signification de la protéinurie et au tableau clinique de la maladie.

On a fait les observations suivantes:

(1) Une biopsie rectale donna des résultats positifs dans sept cas sur neuf, tandis que la biopsie rénale donna des résultats positifs chez huit d'entre eux.

(2) L'amyloïdose fut diagnostiquée chez 17 sur 24 arthritiques avec protéinurie ( 70,8 pour cent).

(3) Le tableau clinique de l'arthrite rhumatismale compliquée d'amyloïdose ne se distinguait pas appréciablement du tableau caractéristique d'une arthrite très avancée. La durée moyenne de l'arthrite rhumatismale fut de 13 ans (étendue de 2 à 26 ans); les lésions articulaires furent de l'Etape III ou IV dans 15 cas; la vitesse de sédimentation globulaire fut de $85 \mathrm{~mm}$./h; une anémie normochrome fut présente dans 14 cas. La protéine C-réactive fut décélée dans le sang de 9 malades; la réaction de Waaler-Rose fut positive dans 9 cas et la réaction de fixation au latex dans 11 cas.

Un traitement stéroïde prolongé fut administré dans 12 cas et un traitement court dans 4 cas. 
L'amyloïdose rénale revêtit l'aspect de syndrome néphrotique dans 12 cas et seulement un d'entre eux eut de la spléno-hépatomégalie avec hyperlipémie prononcée. Les six cas restants, avec protéinurie benigne, accusèrent une clearance de créatinine diminuée comme signe de dommage rénal.

La tension artérielle ne fut nettement augmentée chez aucun malade.

\section{Artritis reumatoide con amiloidosis}

\section{SUMARIO}

En 17 casos de artritis reumatoide se hizo el diagnóstico de amiloidosis secundaria por biopsia renal y/o rectal en 16 casos y de un ganglio linfático en un caso. Una proteinuria fué la indicación de la biopsia. Se pagó atención especial al valor diagnóstico de la biopsia rectal comparada con la renal, a la importancia de la proteinuria y al cuadro clínico de la enfermedad.

Se hicieron observaciones siguientes:

(1) De neuve casos, la biopsia rectal dió siete resultados positivos, mientras que la biopsia renal en los mismos casos dió ocho resultados positivos.
(2) Amiloidosis fué diagnosticada en 17 de los 24 artríticos con proteinuria ( 70,8 por ciento).

(3) El cuadro clínico de la artritis reumatoide complicada de amiloidosis no difería significativamente del cuadro característico de la artritis muy adelantada. La duración media de la artritis reumatoide fué de 13 años (de 2 a 26 años); las lesiones articulares fueron del grado III o IV en 15 casos; la velocidad de sedimentación globular fué de $85 \mathrm{~mm}$./h.; anemia con normocromia fué presente en 14 casos. La proteina C-reactiva fué hallada en la sangre de 9 enfermos; la reacción de Waaler-Rose fué positiva en 9 casos y la reacción de fijación al latex en 11 casos.

Un tratamiento esteroide prolongado fué administrado en doce casos y un tratamiento corto en cuatro casos.

La amiloidosis renal revistió la forma de síndrome nefrótico en 12 casos y sólo uno de ellos tuvo esplenohepatomegalia con hiperlipemia pronunciada. Los demás seis casos, con proteinuria benigna, acusaron, como marca de daño renal, una clearance de creatinina disminuida.

En ningún enfermo fué la tensión arterial netamente aumentada. 
Drs. B. S. Rose and I. M. Prior presented further results on "Gout and Other Metabolic Maladies of the Maori"':

Previous surveys of four Maori tribes were reviewed, and the high prevalence of gout was related to the similar frequent occurrence of obesity, diabetes, and hypertensive, renal, and degenerative cardiovascular disease. Serum uric acid distribution curves showed more hyperuricaemia than in local European populations, with skewing and a tendency to bimodality. A working hypothesis was postulated on the basis that a single gene was responsible for hyperuricaemia with a high degree of polymorphism, environmental (dietary) factors allowing marked manifestation of this latent trait; and other genetic factors influencing the familial incidence of gouty arthritis itself.

Dr. Ray Robinson spoke on "Indomethacin, a New Anti-inflammatory Agent'.

This was used on a series of 79 patients suffering from various forms of relentlessly progressive or continuously painful rheumatic diseases-all of whom had failed to respond adequately to standard treatment with rest, physical therapy, and drugs over a 9-month period.

The erythrocyte sedimentation rate and haemoglobin were not materially affected. No toxic effects were in the haemopoietic, renal, or hepatic system.s. Epigastric pain, nausea, and two cases of gastro-intestinal bleeding were recorded, one in a patient with a quiescent peptic ulcer. Headache, occasionally very severe, was troublesome, but many patients elected to continue despite this. Psychological disturbance, a detachment from reality, was seen in one patient who had been basically unstable before treatment. Another had two epileptic attacks after freedom for 20 years after the initial episodes. Osteo-arthritic lesions and neck and arm pain were not satisfactorily relieved. The dose recommended at first was far too high, and this influenced the figures unfavourably. The following schedule was suggested: $25,50,75$, and $100 \mathrm{mg}$. for 2 days each leading to a gradual increase to 150 or $200 \mathrm{mg}$. daily as necessary. On this routine very little trouble was experienced.

A tendency for the disease to break through this antiinflammatory barrier was noted in some cases after 6 months or more of adequate control.

It was possible, in many cases, to withdraw or to reduce corticosteroid to a minimum.

Dr. J. J. R. Duthie discussed some features of the aetiology of rheumatoid arthritis, including a short account of the current serological and biochemical investigations at Edinburgh and preliminary data on the demonstration of viable bodies in rheumatoid synovia. The very wide and important implication of this work occasioned great interest and the further development of this work will be eagerly awaited.

Drs. I. C. Isdale, K. R. Ridings, and P. W. Tapsell discussed the indications for rheumatic disease surgery, advocating the team approach of physician, surgeon and anaesthetist. They briefly reviewed their results in a series of 180 patients and outlined their indications for various methods of anaesthesia in individual patients.

Other papers presented were:

Dr. R. Howes: "Recent Impressions of London Rheumatic Centres."

Dr. R. Ensor: "Some Points of Rheumatic Pathology."

Dr. R. A. Wigley: "Joint Manifestations of Regional Enteritis."

A group of cases were presented for discussion.

\section{CORRIGENDUM}

It is regretted that in the paper by $\mathrm{K}$. Ennevaara and M. Oka (Annals, 1964, 23, 131), in Table II (p. 135), showing serological changes in eleven cases in the course of 2 to 36 months, a confusion arose between WaalerRose tests "not done" and those which gave a nil result. The correct readings in Cases 10,12, 14, and 15 are as follows:

\begin{tabular}{|c|c|c|c|}
\hline Case No. & $\begin{array}{l}\text { Waaler-Rose Titre } \\
\text { Ist examination }\end{array}$ & $\begin{array}{c}\text { Interval } \\
\text { (mths) }\end{array}$ & $\begin{array}{l}\text { Waaler-Rose Titre } \\
\text { 2nd examination }\end{array}$ \\
\hline $\begin{array}{l}10 \\
12 \\
14 \\
15\end{array}$ & $\begin{array}{c}\mathrm{Nil} \\
32 \\
\text { Not done } \\
250\end{array}$ & $\begin{array}{l}12 \\
12 \\
36 \\
24\end{array}$ & $\begin{array}{l}\text { Nil } \\
\text { Nil } \\
\text { Nil } \\
\text { Nil }\end{array}$ \\
\hline
\end{tabular}

Elsewhere in the Table, $0=$ Not done, as stated in the footnote. 